\title{
Cycle, productivity and must chemical characteristics of varieties of white wine grape
}

\author{
Mara Fernandes Moura ${ }^{1, a}$, Juliana Rocha de Souza ${ }^{2, b}$, Lenon Romano Modesto ${ }^{2, b}$, José Luiz Hernandes ${ }^{1, a}$, \\ and Taiane Silva Santos $2, \mathrm{~b}$ \\ ${ }^{1}$ Scientific reseacher, Centro APTA de Frutas, Instituto Agronômico, Av. Luiz Pereira dos Santos, 1500, Corrupira, Jundiaí, SP, \\ Brasil, CEP: 13214-820 \\ ${ }^{2}$ Postgraduate student inTropical and Subtropical Agriculture of Instituto Agronômico. Av. Barão de Itapura, 1481 Botafogo, \\ Campinas, SP, Brasil, CEP 13020-902
}

\begin{abstract}
The objective of this work was to evaluate five varieties of white grapes destined to winemaking, grafted on the two main rootstocks used in viticulture in São Paulo, Brazil, 'IAC 766 Campinas' and 'IAC 572 Jales'. The experiment was performed on the experimental area of Centro APTA de Frutas in the Jundiaí city, São Paulo state, Brazil. The experimental design was a randomized block with split plot with five replications, the plots represented by varieties and subplots by rootstocks. We evaluated the number of days to budding (NDB), number of days to flowering (NDF) and number of days to maturation (NDM), productivity (Prod) (ton.ha ${ }^{-1}$ ), content of soluble solids (SS), titratable acidity (TA) and maturation index (MI). There was no difference between rootstocks, and there was interaction among rootstocks and varieties for SS and TA. The varieties did not show significant differences for yield, but there was a significant difference for the other variables. We can concluded that among the assessed varieties on both rootstocks, in Jundiaí / SP, the variety SR 501-17 distinguished itself due to its precocity, productivity and chemical quality of the must.
\end{abstract}

\section{Introduction}

Brazilian viticulture is in increasingly expanding, always willing to change in order to improve the vineyards, and consequently, obtaining grapes and wines of a higher quality [1-3].

Brazil presents countless difficulties in producing quality wines, especially those related to environmental factors, such as soil and climate [4]. In addition to it, the production of quality grapes proper for wine production is closely related to the choice of canopies and rootstocks. The interaction of all of these factors, besides directly affecting productivity and some chemical characteristics of the berry, such as $\mathrm{pH}$, soluble solids and titratable acidity, can also affect other important quality parameters such as nutrient absorption, accumulation of phenolic compounds and anthocyanin content [5].

Cultivation of grapes destined to the production of wines and its derivatives comprises around 1,536,100 grapevines and is mainly concentrated in the regions surrounding Sorocaba, which includes the towns of São Roque, Capão Bonito and São Miguel Arcanjo; Campinas, comprising the towns of Serra Negra, Vinhedo, Jundiaí, Itupeva, Itatiba, Jarinu, Jaguariúna and Santo Antônio do Jardim; and Araçatuba, and the towns of Florida Paulista and Lucélia [6].

\footnotetext{
a e-mail: mouram@iac.sp.gov.br;jlhernandes@iac.sp. gov.br

b e-mail: julianarocha_agrofer@hotmail.com;lenon modesto@hotmail.com; ss.taiane@gmail.com
}

In the state of São Paulo, the main grapes cultivars proper for wine production are: Seibel-2, Isabel, Bordô, Niagara Branca, Niagara Rosada, IAC 138-22 'Máximo' and Moscatel. We can notice that there has been a slight increase in the farming of grapes, such as Cabernet Sauvignon, Merlot and Syrah, and the highest growth of hybrid cultivars Máximo and Moscatel. However, a good alternative to wine producers is the white grapes cultivars, because the quality of their wines, in addition to not depending on phenolic maturation, accepts higher levels of total acidity. Little to no information is available in literature regarding the behavior of new white grape varieties in different Brazilian regions [7].

During the last years, we verified through grape producers along the region of Jundiaí-SP, that there is a demand for studies regarding cultivars of grapes proper for wine production, since this is an alternative for the verticalization of grape production, allowing the their processing and the elaboration of beverages, thus increasing the production value [8].

With the phenological study of grapevines we aim to describe and correlate the course of events and their variability with climate and other phenotype events for each and every kind, in order to determine the acclimation of the grapevines to the farming region.

The main phenological stages of a grapevine's vegetative and reproductive cycle are budding, flowering, early maturation and complete maturation (harvest), visually identified when $50 \%$ of the buds, flowers and berries reach each event [10]. 
Determining the physico-chemical properties of wines makes it possible to rate their quality [11]. The berries' composition at the time of harvest, such as the sugars, acids, tannins, non-oxidizable polyphenols content, their antioxidant capacity, scent, oxidoreductive enzymes and microelements are essential for wine quality. All of these composition factors guarantee the distinctive character, quality and is directly related to the cultivar's genetic material, cultural techniques adopted in the vineyard and with the viticulture ecosystem itself. Important elements that compose the grape are absorbed by the root system, for that reason, besides cultivar, climate and soil; the rootstock can play an important role in the grape's composition, determining its quality, as well as the wine's final quality $[5,12]$.

Based on what we presented, the objective of this study was to evaluate the phenological behavior, productivity and quality of must of five grape varieties for white wine in the eastern region of the São Paulo state.

\section{Material e methods}

We carried out the experiment in the experimental area of Centro APTA de Frutas located in the city of JundiaíSP. Which is found at $23^{\circ} 17^{\prime \prime} \mathrm{S}$ and $46^{\circ} 9^{\prime \prime} \mathrm{O}$, with an altitude of 700 to $900 \mathrm{~m}$, with annual rainfall averages of $1,400 \mathrm{~mm}$, an average temperature of $19.5^{\circ} \mathrm{C}$ and a relative humidity of $70.6 \%$. The experimental area's soil type is the Red Cambrian Distrophic [13]. Regarding the number of cold hours, the altitude compensates for the latitude along these regions, thus allowing the farming of temperate climate viticulture. Winter is mild, but subject to rimes, and with low rainfall rates; summer is hot and dry, making fungal diseases, such as anthracnose, mildew, leaf spot, rust, powdery mildew and clump rot, possible threats.

The support system we used was the espalier one, in spaces of $2.0 \times 1.1 \mathrm{~m}$. These two rootstock varieties seeding was carried out on September 2013 and the canopy varieties grafting was done on July 2014. The experimental design was a randomized block design with five replications.

The treatments consisted of combinations from hybrid varieties such as SR 0.501-17, Moscato Embrapa, Moscatel de Jundiaí, BRS Lorena and IAC Madalena, grafted onto the rootstocks IAC 572 'Jales' e IAC 766' Campinas'.

The SR 0.501-17 variety, is a hybrid cultivar, that presents a medium maturity cycle, scent and flavor noticeably Moscatel, a good productivity and tolerance to major fungal diseases [14].

The Moscato Embrapa variety originates wines with a muscatel flavor, typically aromatic. It is resistant to bunch rot, presents a moderate acidity, and it's very well accepted among Brazilian consumers [15].

The Moscatel of Jundiaí variety has vigorous, productive plants, but it's vulnerable to mildew, and presents large, long, winged clusters [14].

The BRS Lorena variety presents a must rich in sugar (soluble solids content around 20 to $22^{\circ}$ Brix) and its acidity is relatively high [16].

The IAC Madalena variety presents medium / late cycles, from its grapes we obtain white, aromatic muscat wines with good acidity, and also, being fit for the production of sparkling wines, both alone and in parts with neutral white ones [14].

The rootstock IAC 572 'Jales' is vigorous, with leaves resistant to major diseases, branches that lignify later and hardly ever has its leaves falling, presenting great rooting and attachment properties [17].

The rootstock IAC 766 'Campinas' is vigorous, perfectly adaptable to the São Paulo's environmental conditions, its leaves are very resistant to diseases [17].

We used an experimental plot composed by five plants. Pruning was performed on August 1st, 2016, when we left two gems per branch.

During the experiment's maintenance, we adopted every cultivation technique practiced by wine producers of the region. With the start of budding, we carried out shoots topping, we then tied them to wires, and lastly, the innotation was performed.

We determined the plant's phenology through weekly visual observations performed after pruning using Eichor Lorentz's methodology [18]. Afterwards we determined the number of days for budding (NDB), the number of days for flowering (NDF), and the number of days for maturity (NDM) in according to the classification proposed by Baillod \& Baggiolini [19].

Harvests were then carried out from December $28^{\text {th }}$, 2016 to January $23^{\text {rd }}, 2017$. We identified the grapes harvesting point from monitoring the maturation curve, taking into account a maximum $\mathrm{pH}$ of 3.5.

We carried out weekly analyzes at the Centro APTA de Frutas Laboratory, using a sample of 30 random berries per treatment.

At the time of harvesting, all of the clusters from each and every plot were weighed and the value obtained, we divided by the number of plants, thus determining the average production rate per plant, expressed in kg.planta ${ }^{-1}$.

In order to estimate the average productivity per hectare, we multiplied the average production per plant from each plot by the number of plants per hectare; the result has been expressed in $\mathrm{tha}^{-1}$.

We determined the must's chemical composition within a sample composed of 100 berries per experimental plot. The must was obtained through the berries manual maceration and then it was homogenized. We used an Atago ${ }^{R}$ digital refractometer to perform a direct refractometry in order to determine the soluble solids (SS) contents, which, in turn, was expressed in ${ }^{\circ}$ Brix; the titratable acidity (AT), expressed as $g$ of tartaric acid $100 \mathrm{~g}-1$ of pulp; And pH, was found using Digimed $(\mathrm{DM}$ $22 \mathrm{pH}$ measurer. We obtained the maturation index from the relationship between the soluble solids content and the titratable acidity, according to the method described by the Institute of Food Technology [20].

At last, we submitted the obtained results to a variance analysis (test F) whilst the average values, we compared them through the Tukey test, at a 5\% probability.

\section{Results and discussion}

There was no significant difference among the rootstocks, and they did not present any interaction with the different varieties, except regarding the soluble solids content and index maturation variables. In addition to the rootstock influence, along the same region, other variables may 
Table 1. Means of number of days for budding (NDB), number of days for flowering (NDF), number of days for ripening (NDM), yield and titratable acidity (AT) in cultivars of white wine grapes on two rootstocks, Jundiaí-SP, 2016.

\begin{tabular}{|c|c|c|c|c|c|}
\hline Varieties & $\begin{array}{l}\text { NDB } \\
\text { (days) }\end{array}$ & $\begin{array}{l}\text { NDF } \\
\text { (days) }\end{array}$ & $\begin{array}{l}\text { NDM } \\
\text { (days) }\end{array}$ & $\begin{array}{l}\text { Prod. } \\
\text { (ton. }^{-1} \text { ) }\end{array}$ & $\begin{array}{l}\mathrm{AT} \\
(\% \quad \text { tartaric } \\
\text { acid })\end{array}$ \\
\hline IAC Madalena & $18,50 \mathrm{a}$ & $54,0 \mathrm{~b}$ & $157,0 \mathrm{~d}$ & 14,1 & $0,70 \mathrm{~b}$ \\
\hline Moscatel de Jundiaí & $17,0 \mathrm{bc}$ & $51,2 \mathrm{c}$ & $171,0 \mathrm{~b}$ & 17,1 & $0,80 \mathrm{a}$ \\
\hline Moscato Embrapa & $18,3 \mathrm{ab}$ & $60,0 \mathrm{a}$ & $164,0 \mathrm{c}$ & 15,4 & $0,58 \mathrm{c}$ \\
\hline $\mathrm{SR}-501$ & $16,8 \mathrm{c}$ & $51,2 \mathrm{c}$ & $150,0 \mathrm{e}$ & 16,1 & $0,67 \mathrm{~b}$ \\
\hline BRS Lorena & $17,8 \mathrm{abc}$ & $54,80 \mathrm{~b}$ & $176,0 \mathrm{a}$ & 14,3 & $0,70 \mathrm{~b}$ \\
\hline \multicolumn{6}{|l|}{ Porta-enxerto } \\
\hline 766 & 17,91 & 54,64 & 163,60 & 15,39 & $0,67 b$ \\
\hline \multirow[t]{2}{*}{$572-1$} & 17,65 & 54,56 & 163,60 & 13,49 & $0,71 \mathrm{a}$ \\
\hline & & & P Value & & \\
\hline Varieties & 0,003 & $<0.001$ & - & 0,712 & $<0.001$ \\
\hline Rootstocks & 0,308 & 0,271 & - & 0,049 & 0,044 \\
\hline Varieties x Rootstocks & 0,941 & 0,239 & 一 & 0,742 & 0,482 \\
\hline $\mathrm{CV}(\%)$ & 6,19 & 3,73 & - & 34,62 & 8,35 \\
\hline
\end{tabular}

Means followed by the same lowercase letter in the column, do not present significant difference between them (Tukey $\leq 0,05)$.

Table 2. Mean values of the soluble solids (SS) and maturation index (MI) variable in cultivars of white wine grapes on two rootstocks, Jundiaí-SP, Brazil, 2016.

\begin{tabular}{|c|c|c|c|c|}
\hline & \multicolumn{2}{|c|}{ SS $\left({ }^{\circ}\right.$ Brix $)$} & \multicolumn{2}{|c|}{ MI } \\
\hline Cultivares & IAC 766 & IAC 572 & IAC 766 & IAC 572 \\
\hline SR 501-17 & $16.80 \mathrm{abB}$ & $18.32 \mathrm{aA}$ & $26.05 \mathrm{bA}$ & $26.70 \mathrm{aA}$ \\
\hline Madalena & $15.10 \mathrm{cA}$ & $14.26 \mathrm{cA}$ & $22.48 b c A$ & $20.24 b A$ \\
\hline Lorena & $17.98 \mathrm{cA}$ & $18.90 \mathrm{aA}$ & $26.20 \mathrm{bA}$ & $16.85 \mathrm{aA}$ \\
\hline Moscatel de JD & $15.5 \mathrm{bcA}$ & $15.88 \mathrm{bbA}$ & $19.78 \mathrm{cA}$ & $19.50 \mathrm{bA}$ \\
\hline Moscato Embrapa & $16.78 \mathrm{abA}$ & $16.36 \mathrm{bA}$ & $31.72 \mathrm{aA}$ & $26.18 \mathrm{aB}$ \\
\hline & \multicolumn{4}{|c|}{ P Value } \\
\hline Varietiies & \multicolumn{2}{|c|}{$<0.001$} & \multicolumn{2}{|c|}{$<0.001$} \\
\hline Rootstocks & \multicolumn{2}{|c|}{0.29} & \multicolumn{2}{|c|}{0.06} \\
\hline Varieties x Rootstocks & \multicolumn{2}{|c|}{$0.03 *$} & \multicolumn{2}{|c|}{0.04} \\
\hline $\mathrm{CV} \%$ & \multicolumn{2}{|c|}{5.21} & \multicolumn{2}{|c|}{9.99} \\
\hline
\end{tabular}

Means followed by the same letters in the column and in the line, do not present significant difference between them (Tukey $\leq 0,05)$.

interfere in the productive behavior of the cultivars, such as the climate conditions in the farming year, pests and/or diseases incidence on the clusters, directly affecting the production, or on the leaves, interfering with the photosynthetic rate.

Grape varieties are characterized by their high sensitivity to biological adversities [21] and the great influence from environmental conditions on physiology and productive behavior [22]. Several factors that affect its phenology ought to be identified in each and every producing region [23].

Although there was no significant difference among them for productivity, the Moscatel de Jundiaí cultivars presented the highest productivity average (17.1 ton.ha ${ }^{-1}$ ), directly followed by the SR 501-17 (16.1 ton.ha $\left.{ }^{-1}\right)$, Moscato Embrapa (15.4 ton.ha ${ }^{-1}$ ) and BRS Lorena cultivars (14.3 ton.ha- $\left.{ }^{-1}\right)$. The IAC Madalena variety presented the lowest one (14.1 ton.ha ${ }^{-1}$ ).

The length of the main grapevines phenological stages during the 2016 cycle are presented in the Table 1. Buds occurred in between 16 and 19 days after pruning. In which, the SR 501-17 variety presented a lower budding and flowering number of days, not that different from the Moscatel de Jundiaí variety.
The classification based on the budding season is of extreme value to the grape producers, once it allows the use of early budding varieties in regions with low risks of late rimes and late budding varieties in regions prone to this phenomenon [24].

Another important factor is to know the grapevine maturation potential in a certain region, its accumulation of sugars and acidity. Colder regions can prolong this period, also adding more polyphenols, which, in turn, allows the elaboration of high quality fine wines [25-27].

Grape maturation started occurring in between 150 and 176 days, with an earlier ripening observed on the SR501 variety (150 days) and a later one on the BRS Lorena variety (176 days). In São Paulo, earlier ripening varieties are required, once there is a possibility of two cycles a year when using early maturation varieties.

For the quality of the must, there were interactions between the varieties and the rootstock regarding the soluble solids contents variable (SS) and maturation index (MI) (Table 2). For both IAC 766 and IAC 572 rootstocks, the BRS Lorena variety presented higher averages $\left(17.98^{\circ}\right.$ Brix and $18.9^{\circ}$ Brix, respectively) not so distant from the SR 501-17 variety (16.8 ${ }^{\circ}$ Brix and $18.32^{\circ}$ Brix, Respectively). All in all, the soluble solids values did not 
differ among rootstocks, except for the SR 501-17 variety that presented a higher average $\left(18.32^{\circ} \mathrm{Brix}\right)$ when grafted on IAC 572 rootstocks.

The appropriate level of SST for quality winemaking should be between 18 and $22^{\circ}$ Brix for white grapes and above $21^{\circ}$ Brix for red ones [28]. In general, the SS levels we obtained from wine intended grape cultivars in the region of Jundiaí are low. Studies carried out in Jundiaí showed that the 'Moscatel de Jundiaí', 'IAC 138-22 Máximo', 'IAC 21-14 Madalena', 'Seibel 10096' and 'Isabel' grape varieties presented content levels of 17.2, 17.0, 16 , 2, 17.2 and $15.9^{\circ}$ Brix, respectively [29]. According to the authors, these low SS levels were found due to the fact that the maturation period of the grapes occurred under conditions of too much water and high day and night temperatures.

Regarding the titratable acidity, the lowest average value we obtained was from the Moscato Embrapa variety $(0.58 \%$ tartaric acid), directly influencing its maturation index (28.95), but this variety did not present differences from the maturation index of SR $501-17$ (26.38) and BRS Lorena varieties (26.53). These values were found due to their own high soluble solids content, whilst a high maturation index depending on soluble solids content is expected. The recommended must's titratable acidity contents are somewhere in between 0.4 and $0.6 \%$ for the production of a quality wine [5]. However, these values should not be considered high because during the winemaking process there is a considerable reduction on the titratable acidity, mainly due to salitification, of tartaric acid precipitation and malolactic fermentation [30]. In addition to it, there are several potential wine styles, for which there will be different levels for optimum acidity, keeping in mind the technical limits already established by oenological experience.

In relation to MI, higher mean values were found in the Moscato Embrapa variety (Table 2). However, this variety when grafted on the rootstock IAC 572, did not present significant difference from the varied SR 501-17 and BRS Lorena, being due the high soluble solids content of the varieties SR 501-17 and BRS Lorena, being more desirable while low acidity is not recommended to elaboration of a quality white wine [5].

\section{Conclusion}

We can concluded that among the assessed varieties on both rootstocks, in Jundiaí / SP, the variety SR 501-17 distinguished itself due to its precocity, productivity and chemical quality of the must.

Fundação de Amparo à Pesquisa do Estado de São Paulo FAPESP.

\section{References}

[1] F.A. Brito Panorama e perspectives da vitivinicultura. In: $7^{\circ}$ Seminário Nacional sobre Fruticultura de Clima Temperado. Resumos. São Joaquim, 7-11 (2006)

[2] L. M. R. Mello Vitivinicultura brasileira: Panorama 2009. Bento Gonçalves: 2010, 4p. (Artigo Técnico)

[3] L. I. Malinovski, L. J. Welter, A. F. Brighenti, H. J. Vieira, M. P. Guerra, A. L. Silva Highlands of Santa
Catarina/Brazil: A region with high potential for wine production. Acta Horticulturae 931, 433-440 (2012) http://dx.doi.org/10.17660/ActaHortic. 2012.931.51

[4] J. P. P. Gardin et al. Ácido abscísico e etefom: influência sobre a maturação e qualidade das uvas Cabernet Sauvingnon. Revista Brasileira de Fruticultura, Jaboticabal 34(2), p. 321-327 (2012)

[5] R.V. da Mota, C. R. de Souza, A. C. Favero, C. P. C. Silva, E. L. do Carmo, A. R. Fonseca, M. de A. Regina Produtividade e composição físicoquímica de bagas de cultivares de uva em distintos portaenxertos. Pesquisa Agropecuária Brasileira 44, 576-582 (2009). doi: 10.1590/ S0100204X2009000600005

[6] S. C. S. Bueno, et al. Vinhedo paulista. Campinas: Coordenação de Assistência Técnica Integral, 2010, $256 \mathrm{p}$.

[7] M. A. Regina, et al. Influência da altitude na qualidade das uvas 'Chardonnay' e 'Pinot Noir' em Minas Gerais. Revista Brasileira de Fruticultura, Jaboticabal 32(1), 143-150 (2010)

[8] L. C. Silva, et al. Níveis de produção em vinhedos de altitude da cv. Malbec e seus efeitos sobre os compostos fenólicos. Revista Brasileira de Fruticultura, Jaboticabal 30(3), 675-680 (2008)

[9] G. Jones, R. Davis Climate influences on grapevine phenology, grape composition, and wine production and quality for Bordeaux, France. American Journal of Enology and Viticulture, Davis 51, 249-261 (2000)

[10] D. H. Lorenz, K.W. Eichhorn, H. Bleiholder, R. Klose, U. Meier, E. Weber Phenological growth stages of the grapevine (Vitis vinifera L. ssp. vinifera) - codes and descriptions according to the extended BBHC scale. Australian Journal of Grape and Wine Research 1, 100-103 (1995)

[11] M. B. M Castilhos, V. L. Del Bianchi Caracterização físico-química e sensorial de vinhos brancos na Região Noroeste de São Paulo. Holos, Natal 4, 148 158 (2011)

[12] L. A. Rizzon, M. B. G. Salvador, A. Miele Teores de cátions dos vinhos da Serra Gaúcha. Ciência e Tecnologia de Alimentos, 28, 635-641 (2008). doi: 10.1590/S010120612008000300020

[13] EMBRAPA. Sistema brasileiro de classificação do solo. Brasília: Embrapa Produção de Informação; Rio de Janeiro: Embrapa Solo 42 (1999)

[14] J. S. I. de Souza, MARTINS, F. Picarelli, Viticultura Brasileira: Principais Variedades e suas Características. Piracicaba: FEALQ $\mathbf{3 6 8}$ (2002)

[15] U. A. Camargo, M. C. Zanuz Embrapa 131-Moscato Embrapa Đ Nova cultivar para a elaboração de vinho branco. Bento Gonçalves: Embrapa Uva e Vinho, 1997. 4p. (Embrapa Uva e Vinho. Comunicado Técnico, 24)

[16] U. A. Camargo, C. C. Guerra BRS Lorena: cultivar para a elaboração de vinhos aromáticos. Bento Gonçalves: Embrapa Uva e Vinho, ago. 2001. 4p. (Embrapa Uva e Vinho. Comunicado Técnico, 39)

[17] F. M. Pereira, H. F. Leitão Filho Caracterização botânica de porta-enxertos de videira. Campinas: Instituto Agronômico 19 (1973) (Boletim técnico, 7) 
[18] K.W. Eichorn, D. H. Lorenz Phaenologische Entwicklungstadien der Rede. European and Mediterranean Plant Protection Organization, Paris 14(2), 295-298 (1984)

[19] M. Baillod, M. Baggiolini Les stades répères de la vigne. Revue Suisse de Viticulture Arboriculture Horticulture, Lausanne 28, 7-9 (1993)

[20] Instituto de Tecnologia de Alimentos (1990) Análises químicas dos alimentos. Manual técnico. Campinas, Ital, 120p.

[21] P. R. Merz, T. Moser, J. Hool, A. Kortekamp, G. Buchholz, E. Zyprian, J. Bogs The transcription factor VvWRKY33 is involved in the regulation of grapevine (Vitis vinifera) defense against the oomycete pathogen Plasmopara viticola. Physiologia Plantarum 153, p. 365-380, doi: 10.1111/ppl.12251 (2014)

[22] A. M. Rosa, et al. Fertilidade e reservas de carbono e nitrogênio em gemas de ramos das viníferas 'Cabernet Sauvignon' e 'Nebiolo'. Revista Brasileira de Fruticultura 36, 576-585 (2014). doi: 10.1590/01002945198/13

[23] T. C. Tomazetti, et al. Fenologia e acúmulo térmico em videiras viníferas na região da Fronteira Oeste do Rio Grande do Sul. Pesq. Agropec. Bras., [s.l.], 50(11), p.1033-1041 (2015) WINKLER, A.J. Viticultura. 6.ed. México: Editorial Continental,1 980, 791p.

[24] F. Mandelli, M. A. Berlato, J. Tonietto, H. Bergamaschi Fenologia da videira na Serra Gaúcha Pesquisa Agropecuária Gaúcha 9, 129-144 (2003)
[25] E. Brighenti, J. Tonietto, O clima de São Joaquim para a viticultura de vinhos finos: classificação pelo sistema CCM geovitícola. In: CONGRESSO BRASILEIRO DE FRUTICULTURA, 8., 2004, Florianópolis, SC. Anais eletrônicos... Florianópolis: SBF (2004) 4p. (CD-ROM)

[26] E. F. Gris, V. M. Burin, E. Brighenti, H. Vieira, M. T. Bordignon-Luiz Phenology and ripening of Vitis vinifera $L$. grape varieties in São Joaquim, southern Brazil: a new South American wine growing region. Ciencia e Investigación Agraria 37, 61-75 (2010)

[27] Borghezan, Marcelo et al. Comportamento vegetativo e produtivo da videira e composição da uva em São Joaquim, Santa Catarina. Pesquisa Agropecuária Brasileira, Brasília 46(4), 398-405 (2011)

[28] Brighenti, Alberto Fontanella et al. Desempenho vitícola de variedades autóctones italianas em condição de elevada altitude no Sul do Brasil. Pesq. Agropec. Bras. 49(6), 465-474 (2014) J. L. Hernandes, P. Júnior, M. J, A. O. Santos, M. A. Tecchio Fenologia e produção de cultivares americanas e híbridas de uvas para vinho, em JundiaíSP. Revista Brasileira Fruticultura, 32, 135-142 (2010). doi: 10.1590/ S0100-29452010005000040

[29] L. A. Rizzon, J. Meneguzzo, L. Manfroi, Processamento de uva, vinho tinto, graspa e vinagre (2004)

[30] T. das G. S. Orlando, M. J. Pedro Júnior, A. O. Santos, J. L. Hernades, Ciênc. Agrotec. 32(3) (2008) 